\title{
Detection and Identification of Tomato Leaf Curl Virus (ToLCV) using Molecular Technique - PCR Method
}

\author{
Jotshana Manik Maske ${ }^{1 *}$, Amol Dadarao Sable ${ }^{1}$ and Prashant Bhausaheb Kardile ${ }^{2}$ \\ ${ }^{1}$ Department of Plant Biotechnology, SDMVM's College of Agricultural Biotechnology, \\ Georai Tanda, Paithan Road, Aurangabad (M.S.)-431001, India \\ ${ }^{2}$ Department of Agricultural Botany, Dadasaheb Patil college of Agriculture, Dahegaon, \\ Auranagabad (M.S.) - 423715, India
}

*Corresponding author

\begin{abstract}
A B S T R A C T
The cultivated tomato (Solanum lycopersicum L.) is economically one of the most

Keywords

Tomato, ToLCV, PCR

Article Info

Accepted:

20 March 2018

Available Online:

10 April 2018

important and widely grown plants of the Solanaceae family. Epidemics of Tomato leaf curl virus associated with upsurge of whiteflies (Bemasia tabacci) on tomato crop has been frequently reported which up to $100 \%$ yield losses (Shelat, et.al, 2014). In all twenty six samples were collected to see the presence of tomato leaf curl virus (ToLCV). Polymerase chain reaction (PCR) in the moist sensitive approach to detect a minute amount of viral nucleic acid it is the most method to amplified geminvirus as they replicate via-doublestranded, circular DNA from. In this study, geminivirus specific detergents primer was employed to detect ToLCV occurring in it vector whitefly Bemisia tabaci by PCR based approach. The presence of virus was observed through PCR method with specific primer CPAV1 forward and reveres on different annealing temperature range from $52^{\circ} \mathrm{C}$ to $56^{\circ} \mathrm{C}$. The presence of virus was observed at $54^{\circ} \mathrm{C}$ annealing temperature in sample no. $4,11,15$, $22,24,25,26)$ and confirm the presence of ToLCV.
\end{abstract}

\section{Introduction}

The cultivated tomato (Solanum lycopersicum L.) is economically one of the most important and widely grown plants of the Solanaceae family. It has been one of the first crop plants for which a genetic linkage map was constructed (Rick, 1975). Tomato leaf curl disease (ToLcD) is a serious and threatening disease of tomato causing losses of up to $100 \%$ various part in the world. The characteristically have ssDNA as genome of some bengomo virus is mono partite (DNA a alone), while a majority have bipartite genome DNA A\&B (Shiva Lingam, et al., 2007) However, there were substantial differences between genotypes in disease incidence, spread, symptom severity and crop yield (Castilillo et al., 2000). Tomato leaf curl disease (ToLCD) is associated with begomovirus, with their generic name as tomato leaf curl virus ToLCVs. Exist both with mono/bipartite genome, whereas ToLCVs carry mono partite genome. For 
management of these viruses, three resistance locii Ty 1 to Ty 3 are being deployed, with provides different degree of resistance. In the plant, the virus develops within the phloem and induces cytological changes (Channarayappa et al., 1992). Symptoms appear only 15 day after inoculation. Tomato plants infected at an early stage are severely stunted; their terminal and auxiliary shoots are erect, and their leaflets are reduced in size and abnormally shaped. Leaves that develop soon after infection are cupped downward, whereas leaves developing later are prominently chlorotic and deformed, with leaf margins rolled upwards and curling between the veins. No flower symptoms are observed but dropping of flowers is common (Abou-jawdah et al., 1995).

The life cycle of whitefly is 18 to 28 days from egg to adult in warm weather and 30 to 48 days in winter. At $221 \mathrm{c}^{\circ}$ the greenhouse whitefly completes its life cycle in about 28 days (Abdullah and Singh, 2004). Reference is for analyzing the internal anatomy of whitefly species. Several publications have focussed on the anatomy of B. tabaci mouthparts (Rosell et $a l ., 1995)$, anterior alimentary canal (Hunter $e t$ al., 1996), and digestive tract, filter chamber and salivary glands (Cicero et al., 1995; Harris et al., 1995, 1996; Ghanim et al., 2001). One of the important damage cause by the whitefly is vectoring various plant viruses transmitted by whiteflies cause over 114 diseases of vegetables and fibers crops worldwide and 111 of those virus species are vectored by the species $B$. tabaci has a circulative mode of transmission, requiring an average of $6-12 \mathrm{hr}$ prior to be transmission event.

The present study aims to detection and identification of Tomato leaf curl virus using molecular technique with two objectives. 1. To isolate DNA from tomato sample.2. To detect tomato leaf curl virus (ToLCV) by PCR method.

\section{Materials and Methods}

The present study "Tomato leaf curl virus detection by PCR Method" carried out at Department of Plant Biotechnology SDMVM's College of Agricultural Biotechnology, Georai Tanda, Paithan Road, Aurangabad (M.S.), 431001, during Jan-2016 to March-2016, with objects to detection and identification of tomato leaf curl virus (ToLCV) by using molecular technique. Chemicals used for present study were of good quality (AR-grade) from various agencies.

\section{PCR amplification}

Good quality genome DNA isolated from different Tomato sample. The ToLCV specific primer CPAV1.was subjected to PCR reaction to detection of ToLCV in different sample. The composition of PCR reaction is presented in table 1 .

\section{Procedure}

Sterile micro centrifuge tubes were numbered and placed on PCR tube stand.

$0.5 \mu 1$ of DNA was added to each PCR tube followed by $637 \mu 1$ master mix.

$1 \mu \mathrm{l}$ of each forward and reverse primer was added in each PCR tube respectively. Separately transfer $24.5 \mu 1$ PCR master mix in PCR tube and add $0.5 \mu 1$ DNA sample added.

PCR was run on the programme thermal cycler with the following by programme:

\section{Results and Discussion}

\section{Source of tomato leaf sample}

Twenty six tomato leaf samples were collected from Nidhona village farm in Jalna (Fig. 1). 
Fig.1 Tomato leaf sample used for detection of tomato leaf curl virus (TLCV)
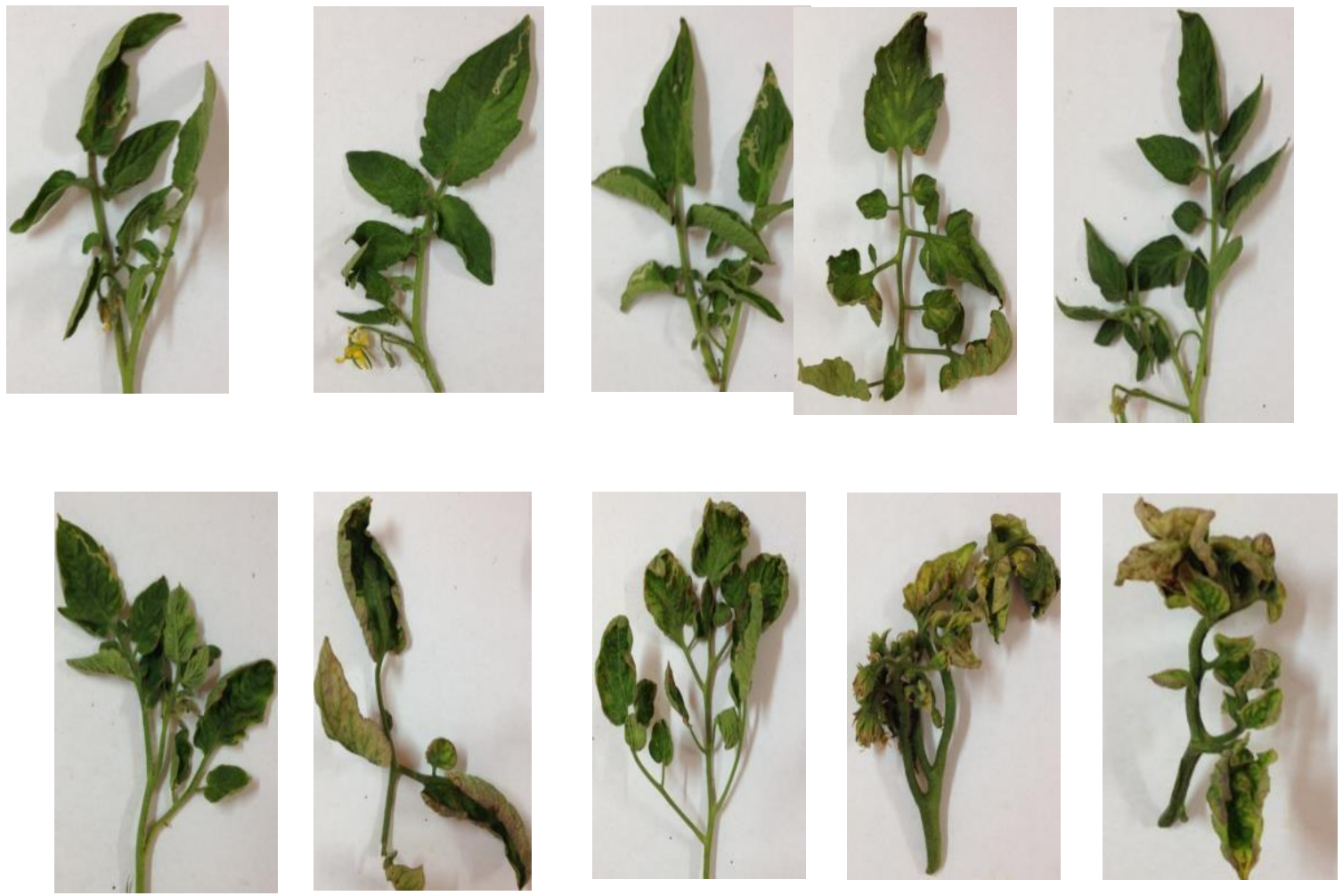

Fig.2 DNA band of different tomato leaf sample

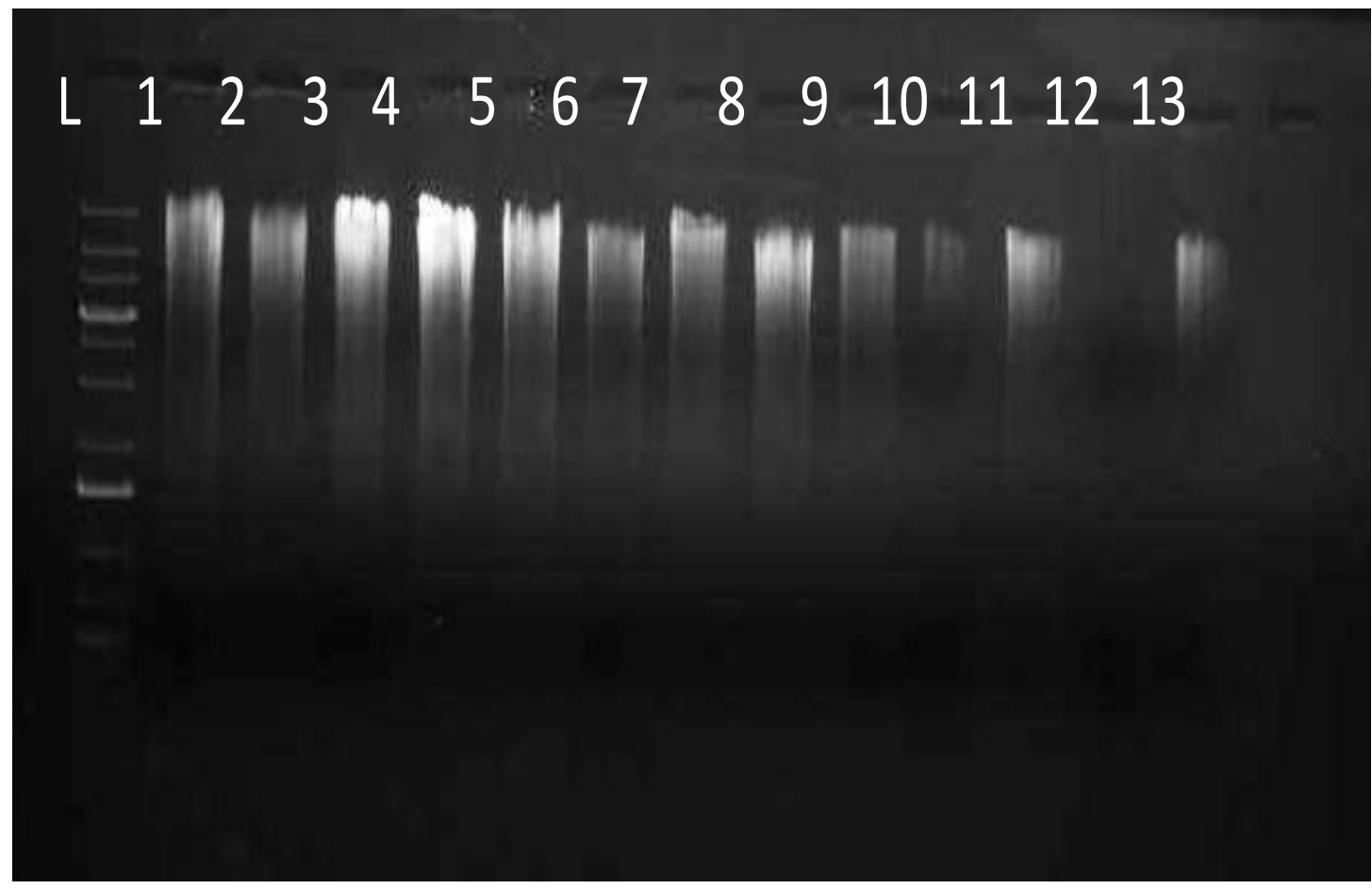


Int.J.Curr.Microbiol.App.Sci (2018) 7(4): 2546-2551

Fig.3 Amplification of DNA band

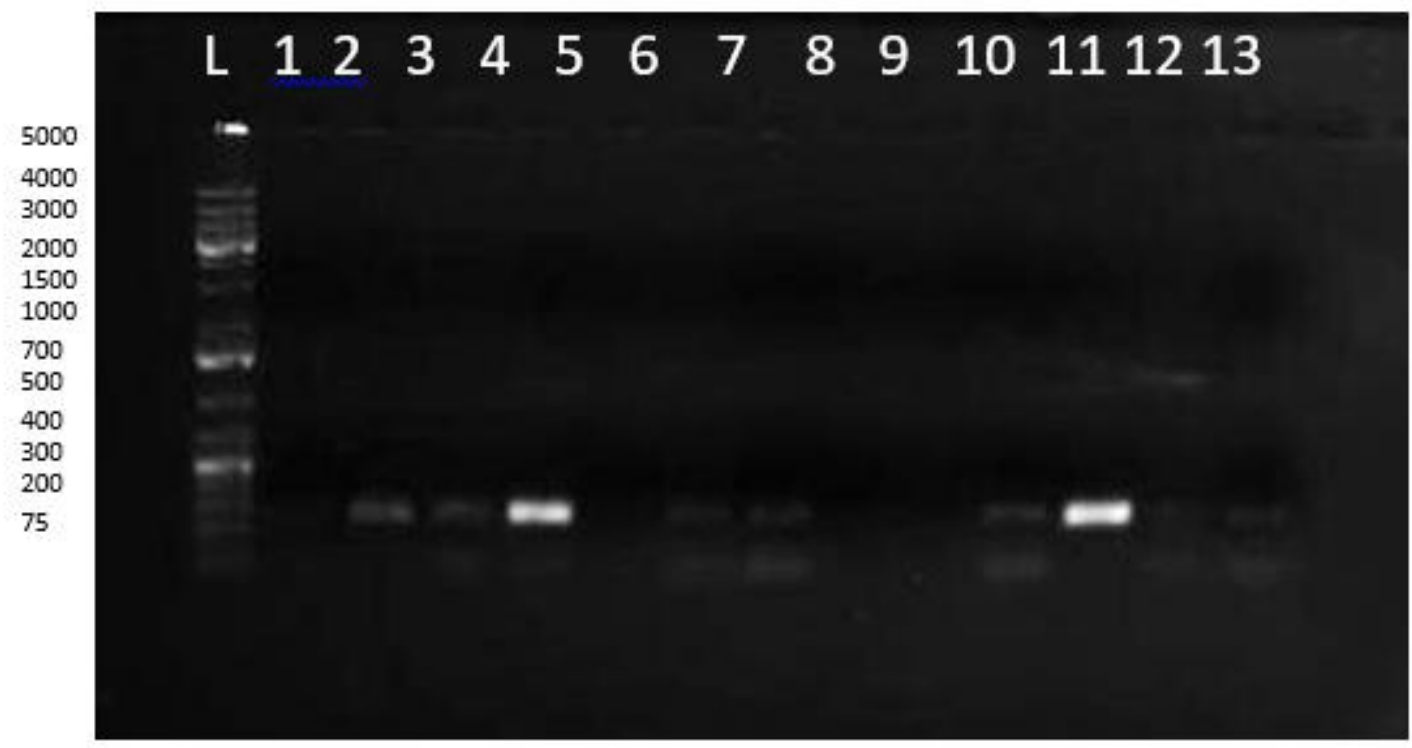

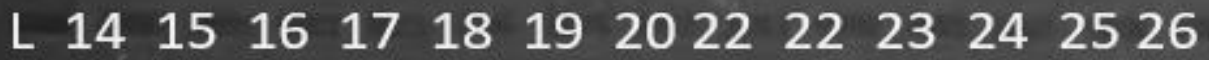

5000

4000

3000

2000

1500

1000

700

500

400

300

200

75

Table.1 Composition of PCR reaction mixture

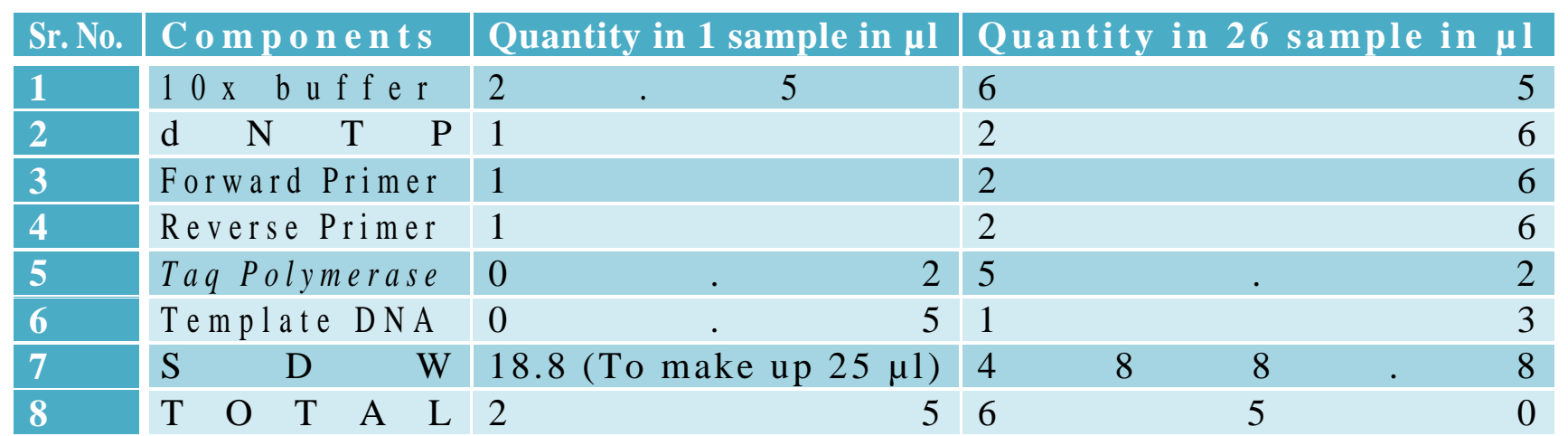


We screened the 26 samples for Tomato leaf curl virus (ToLCV). The collected samples were subjected to PCR amplification with primer CPAV1 (Monoprimer)

\section{Isolation of genomic DNA}

Genomic DNA isolated from tender leaves of selected 26 different Tomato sample. A good quality genomic DNA isolation by using CTAB method.

\section{DNA confirmation}

Isolated genomic DNA from each Tomato leaf sample was loaded on $1 \%$ agarose gel electrophoresis to determine DNA quality. DNA sample as shown in figure 2.

\section{PCR amplification}

The collected tomato leaf sample (possible symptoms of ToLCV) was subjected to PCR amplification for detection of ToLCV with specific primer, CPAV1. After completion of the cycles keep the samples at $4^{\circ} \mathrm{C}$ till electrophoresis. Samples were loaded on $1 \%$ gel electrophoresis (Fig. 3).

These banding pasterns seen under gel doc. Out of 26 sample PCR amplification with ToLCV specific primer, sample 4, 11, 15, 22, 25 and 26 were shown presence 6 bands. It means these samples shown negative means not infected to ToLCV. 1stband is of $400 \mathrm{bp}$, 2ndband is of 430, 3rd band is of 400, 4thband is of 500, 5thband is of $530 \mathrm{bp}$, 6thband is of $480 \mathrm{bp}, 7^{\text {th }}$ band is of $490 \mathrm{bp}$.

In present study we were isolated DNA from infected tomato leaf sample and after PCR by primer (CPAV1). We got positive result for Tomato leaf curl virus in some sample. We selected or collected 26 samples from different region and after screening for virus we analyzed that out of 26 samples we found
TLCV in following lanes 4, 11, 15, 22, 24, 25, 26. The underlying reasons for some plants of Fiona not showing symptoms in the glasshouse are unknown but could be due to several reasons including the multiple infections with ToLCVs. Viral DNA from weed and whitefly-mediated transmitted. Degenrate DNA B-specific PCR primer has not allowed to amplify from plant infected by known bipartite begomovirus. The full length 2759 nucleotide DNA-A-like viral genome was sequenced, similarly to other monopartite ToLCV. Isolates from Bangalore constitute of a group of virus separate from this northern India (Muniyappa et al., 2000; Kirthi et al., 2002). The importance of this disease has promted a great need for a rapid identification of ToLCV in it host and vector One primer pair amplified ToLCV DNA fragment about $1.1 \mathrm{~kb}$ representing partly replicated gene, intergenic reagion and partly coat protein amplified fragment of about $0.5 \mathrm{~kb}$ was obtain. This approach is highly useful for and early detection of ToLCV occurring very small amount in the vector B. tabaci, its amplification in geminivirus mangment strategies and their differentiation and being discussed (Khan, 1999).

Unfortunately the tomato crop is highly susceptible to fungal and viral disease viruses are playing the major role and put the farmer in to the huge losses. Amongst the virus tomato leaf curl virus play major role considering the importance of the virus disease, the present project has been undertaken. In all twenty six samples were collected to see the presence of tomato leaf curl virus (ToLCV). The presence of virus was observed through PCR method with specific primer CPAV1 forward and reveres on different annealing temperature range from $520 \mathrm{C}$ to $560 \mathrm{C}$. The presence of virus was observed at $540 \mathrm{C}$ annealing temperature in sample no. 4, 11, 15, 22, 24, 25, 26) and confirm the presence of ToLCV. 


\section{References}

Abou-Jawdah (1995), Detection of tomato yellow leaf curl Gemini virus (ToLCV) by a digoxigenin-labelled DNA probe to phytopathologia, J. mediterranea, 34: 52-57.

Cicero. J.M. Hebert. E, Webb.S. E. (1995), the alimentary canal of Bemisia tabaci an Trialeurodes abutilon (Homopterous, Sternorrhynchi): histology, ultra structure and correlation to function. J. Zoomorpholog 115:31-39.

Ha, Combs S, Revill P, Harding R, Dale J (2008), molecular characterization of begomovirus and DNA setalite from Vietnam. Journal of virology 89:312326.

Hunter W, Hiebert E, Webb S E, Polston J E. and Tsai H T. (1996), Precibarial and cibarichemosensilla in the whitefly, Bemisia tabaci (Gennadius) (Homoptera: Aleyrodidae). International Journal of Insect Morphology and Embryology 25:295304.

Khan, J.A., (1999) Detection of tomato leaf curl geminivirus in its vector Bemisia tabaci. Indian journal of expt. Biology, 38:512-515.

Kirthi N, Maiya SP, Murthy MRN and Savithri HS (2002), Evidence of recombination among the tomato leaf curl virus strains/species from
Bangalore, India, J. Archives of Virology 147: 255-272.

Muniyappa V. Swanson MM, Duncan GH and Harrison BD (199lb) Particle purification, properties and epitope variability of Indian tomato leaf curl geminivirus. Annals of Applied Biology, 118: 595-604.

Rick, C.M. (1975). Hybridization between Lycopersicon esculantum and Solanum pennellii phylogenetic and cytogenetic singnificance proc. Natl.Acad.Sci.USA Vol46, 78-82.

Rosell, R. Lichty, J. E., and Brown, J. K. (1995).Ultrastructure of the mouthparts of adult sweet potato whitefly, Bemisia tabaci (Gennadius) (Homoptera: Aleyrodidae). International Journal of Insect Morphology and Embryology 24:297-306.

Shelat, M., (2014): Prevalance and distribution of Tomato leaf curl virus in major agroclimatic zone of Gujarat. J. Advance in Bioscience and Biotechnology.5:1-3.

Sivalingam, P.N., (2007) PCR based diagnosis of begomovirus associated with tomato leaf curl disease in India J. plant biochemistry \& biotechnogy, 15(1):17-22.

Tomato production in world FAO report 2015 (FAO statistic). In India \& Maharashtra FAO and Dept. of Horticulture, India Report.

\section{How to cite this article:}

Jotshana Manik Maske, Amol Dadarao Sable and Prashant Bhausaheb Kardile. 2018. Detection and Identification of Tomato Leaf Curl Virus (ToLCV) using Molecular Technique - PCR Method. Int.J.Curr.Microbiol.App.Sci. 7(04): 2546-2551.

doi: https://doi.org/10.20546/ijcmas.2018.704.291 